MaPan : Jurnal Matematika dan Pembelajaran

p-ISSN: 2354-6883 ; e-ISSN: 2581-172X

Volume 5, No 2, December 2017 (216-235)

DOI: https://doi.org/10.24252/mapan.v5n2a5

\title{
PENGARUH PENERAPAN PENDEKATAN REALISTIK SETTING KOOPERATIF TERHADAP KEMAMPUAN KOMUNIKASI MATEMATIKA SISWA KELAS VIII
}

\author{
Andi Alim Syahri \\ Jurusan Pendidikan Matematika FKIP Unismuh Makassar \\ Kampus: Jl. Sultan Alauddin No. 259, Gunung Sari, Makassar, Sulawesi Selatan \\ E-mail: alim_fadhil@yahoo.co.id
}

Submitted: 04-10-2017, Revised: 31-10-2017, Accepted: 31-10-2017

\begin{abstract}
Abstrak:
Penelitian ini bertujuan untuk mengetahui pengaruh pembelajaran matematika melalui penerapan pendekatan realistik setting kooperatif pada siswa kelas VIII SMP Muhammadiyah 6 Makassar tahun ajaran 2017/2018. Jenis penelitian ini adalah penelitian pre-eksperimen yang melibatkan satu kelas sebagai kelas eksperimen tanpa adanya kelas kontrol dengan desain penelitian one group pre-test and post-test design. Subjek dalam penelitian ini adalah kelas $\mathrm{VIII}_{\mathrm{B}}$ sebanyak 33 orang siswa yang terdiri dari 12 orang laki-laki dan 21 orang perempuan. Penelitian dilaksanakan selama 6 kali pertemuan. Instrumen dalam penelitian ini adalah tes untuk melihat kemampuan komunikasi tulisan siswa, lembar observasi untuk mengamati kemampuan komunikasi lisan siswa selama pembelajaran berlangsung, lembar observasi keterlaksanaan pembelajaran untuk mengamati kemampuan guru dalam mengelola pembelajaran sesuai dengan RPP serta lembar angket untuk mengetahui respons siswa terhadap pembelajaran melalui penerapan pendekatan realistik setting kooperatif. Hasil penelitian menunjukkan bahwa: (1) rata-rata kemampuan komunikasi matematika siswa sebelum dan setelah diajar dengan pendekatan realistik setting kooperatif secara berturut-turut adalah 6,15 dan 29,93 dari skor ideal 60 dengan ratarata skor gain ternormalisasi sebesar 0,44 yang berarti peningkatannya berada pada kategori sedang, (2) rata-rata persentase frekuensi kemampuan komunikasi lisan siswa dikatakan berhasil karena perolehan rata-rata persentase $76,63 \%$, (3) rata-rata keterlaksanaan pembelajaran yaitu 3,6 dan ini berada pada kategori terlaksana sangat baik, dan (4) angket respons siswa menunjukkan bahwa respons siswa terhadap pembelajaran pendekatan realistik setting kooperatif cenderung positif dengan persentase $88 \%$. Dari hasil penelitian ini, dapat disimpulkan bahwa penerapan pendekatan realistik setting kooperatif berpengaruh positif terhadap kemampuan komunikasi matematika siswa kelas VIII SMP Muhammadiyah 6 Makassar.
\end{abstract}

Kata Kunci: Pendekatan Realistik, Kooperatif, Kemampuan Komunikasi Matematika 


\title{
THE INFLUENCE OF REALISTIC SETTING COOPERATIVE APPROACH TO COMMUNICATION SKILL MATHEMATICS' STUDENTS OF VIII
}

\begin{abstract}
:
This study aims to determine the effect of learning mathematics through Realistic Cooperative Setting Approach to student's mathematics' communication skill of VIII grade of SMP Muhammadiyah 6 Makassar academic year 2017/2018. This Pre-Experiment research involved one class as a case study without control class with One-Group Pre-Test and Post-Test design. The subject of this research were 33 student's of VIII $I_{B}$ consist of 12 male and 21 female. The research were conducted in 6 meeting. The instrument of this research were test to saw the students' written communication ability, observation sheet to observed students' oral communication ability during the learning process, observation sheet of learning implementation to observed teacher ability in managed learning process in appropriate with RPP and questionnaire to measured the student response in learning trough Realistic Cooperative Setting Approach. The result of this research showed that: (1) most of the students' mathematical communication skill before and after taught by Realistic Cooperative Setting Approach were successive 6,15 and 29,93 from the ideal 60 with average normalized gain score 0.44 means that increase was in the medium category, (2) the average percentage of frequency of the students' oral communication ability was $76,63 \%$, (3) the average implementation of learning was 3,6 in good category, and (4) the questionnaire showed that students' response to Realistic Cooperative Setting Approach inclined to be positive with percentage 88\%. From the result of this research, can be concluded that the application of Realistic Cooperative Setting Approach influenced the student's mathematics' communication skill of VIII grade of SMP Muhammadiyah 6 Makassar.
\end{abstract}

Keywords: Realistic Approach, Cooperative, Mathematics Communication Skiil

How to Cite: Syahri, A. A. (2017). Pengaruh Penerapan Pendekatan Realistik Setting Kooperatif terhadap Kemampuan Komunikasi Matematika Siswa Kelas VIII. MaPan : Jurnal Matematika dan Pembelajaran, 5(2), 216-235.

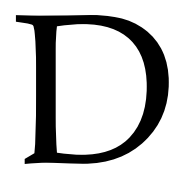
alam kurikulum di Indonesia dijelaskan bahwa komunikasi matematika merupakan salah satu tujuan dari pembelajaran matematika. Menurut Permendiknas (Peraturan Menteri Pendidikan Nasional) Indonesia Nomor 23 tahun 2006, melalui pelajaran matematika diharapkan siswa memiliki kemampuan: (1) memahami konsep matematika, menjelaskan keterkaitan antar konsep dan mengaplikasikan konsep atau algoritma secara luwes, akurat, efisien, dan tepat dalam pemecahan masalah, (2) menggunakan penalaran pada pola sifat, menyusun bukti, atau menjelaskan gagasan dan pernyataan matematika, (3) memecahkan masalah yang meliputi kemampuan memahami masalah, merancang model matematika, menyelesaikan model dan menafsirkan solusi yang diperoleh, (4) 
mengomunikasikan gagasan dengan simbol, tabel, diagram atau media lain untuk menjelaskan keadaan atau masalah, dan (5) memiliki sifat menghargai kegunaan matematika dalam kehidupan, yaitu rasa ingin tahu, perhatian dan minat dalam pembelajaran matematika, serta sikap ulet dan percaya diri dalam memecahkan masalah.

Berdasarkan tujuan pembelajaran matematika tersebut, pada poin keempat dapat dilihat bahwa komunikasi matematika merupakan salah satu kemampuan dasar yang diharapkan tercapai melalui belajar matematika. Kemampuan komunikasi matematika merupakan kemampuan seseorang dalam mengomunikasikan ide-ide dan pikiran matematika.

Baroody (Ansari, 2016: 5) menyebutkan setidaknya ada 2 alasan penting, mengapa komunikasi dalam matematika perlu ditumbuhkembangkan di kalangan siswa, yaitu (1) mathematics as language, artinya matematika tidak hanya sekadar alat bantu berpikir ( $a$ tool to aid thinking), alat untuk menemukan pola, menyelesaikan masalah atau mengambil kesimpulan, tetapi matematika juga sebagai suatu alat yang berharga untuk mengomunikasikan berbagai ide secara jelas, tepat dan cermat, (2) mathematics learning as social activity, artinya sebagai aktivitas sosial dalam pembelajaran matematika, matematika juga sebagai wahana interaksi antar siswa, dan juga komunikasi antar guru dan siswa. Hal ini merupakan bagian terpenting untuk mempercepat pemahaman matematika siswa.

Oleh karena itu, komunikasi matematika merupakan hal penting yang harus dicapai dalam proses pembelajaran matematika. Kemampuan komunikasi sangat menunjang terhadap kompetensi siswa. Untuk melihat apa penyebab rendahnya kemampuan komunikasi matematika siswa, maka salah satu yang perlu dicermati adalah proses pelaksanaan pembelajaran, karena pada saat proses pembelajaranlah materi pelajaran dapat dipahami oleh siswa (Arends, 2008). Rendahnya kemampuan siswa tidak terlepas dari peran guru dalam mengelola pembelajaran. Setelah peneliti melakukan observasi di kelas VIII $_{B}$, peneliti menemukan realitas yang terjadi dalam penyelenggaraan kegiatan belajar mengajar mata pelajaran matematika, yaitu pendekatan pembelajaran yang digunakan masih berpusat kepada guru.

Dengan demikian perlu dicari alternatif untuk mengatasi permasalahan tersebut. Hal yang dapat dilakukan dalam pembelajaran matematika adalah guru seharusnya dapat memilih dan menggunakan pendekatan pembelajaran yang tepat, sehingga siswa dapat memahami konsep matematika dengan baik dan mampu mengembangkan kemampuan menyampaikan informasi atau 
mengomunikasikan gagasan dari konsep matematika tersebut. Salah satu alternatif pembelajaran yang mungkin dapat mengembangkan kemampuan komunikasi matematika siswa adalah pembelajaran dengan pendekatan realistik setting kooperatif.

Pendekatan realistik adalah salah satu alternatif pendekatan pembelajaran yang dapat meningkatkan pemahaman konsep dan komunikasi matematika siswa. Dalam pendekatan realistik, dunia nyata digunakan sebagai titik awal untuk pengembangan ide dan konsep matematika. Fauzan (2002: 35) menjelaskan bahwa proses pengembangan konsep dan ide matematika dimulai dari kehidupan nyata, dan menghubungkan solusi yang didapatkan, kembali kepada kehidupan nyata, sehingga dapat dikatakan bahwa yang dilakukan dalam pembelajaran matematika adalah mengambil suatu permasalahan berdasarkan kenyataan, menjadikannya sebagai proses matematika, dan membawakannya lagi kepada kenyataan. Semua proses ini menuntun kepada pengertian matematika secara konseptual (conceptual matematization). Penggunaan masalah realistik sebagai pangkal tolak pembelajaran memberikan berbagai keuntungan, antara lain siswa menjadi termotivasi belajar matematika, siswa menjadi bersikap positif terhadap masalah, dan siswa akan tertantang untuk memecahkan dengan berbagai cara (Sagala, 2010). Melalui pendekatan realistik, siswa diberi kesempatan untuk mengonstruksi sendiri pengetahuan matematika formalnya melalui masalah-masalah realitas yang ada. Sehingga siswa termotivasi untuk belajar matematika secara nyata dan dapat mudah mengomunikasikannya baik dalam bentuk tulisan, gambar maupun melalui lisan.

Sementara model pembelajaran kooperatif mendukung perencanaan strategi mengajar yang diterapkan untuk menyampaikan materi bahan ajar kepada siswa agar dapat memberikan iklim kondusif dalam perkembangan daya nalar, meningkatkan keaktifan dan kreativitas siswa serta kemampuan komunikasinya (Trianto, 2011). Salah satu aspek penting dalam cooperative learning adalah bahwa selain model itu membantu meningkatkan perilaku kooperatif dan hubungan kelompok yang lebih baik di antara siswa, pada saat yang sama ia juga membantu siswa dalam pembelajaran akademiknya.

Jika pendekatan realistik dipadukan dengan model pembelajaran kooperatif yang mengajarkan siswa belajar secara bekerja sama dan saling membantu dalam hal pemecahan masalah matematika, maka diharapkan akan memberi efek terhadap komunikasi matematika siswa. 


\section{KEMAMPUAN KOMUNIKASI MATEMATIKA}

Secara etimologi, istilah komunikasi berasal dari bahasa Latin, yaitu communicatio, dan bersumber dari kata communis yang berarti sama. Komunikasi pada hakikatnya merupakan proses penyampaian pesan dari pengirim kepada penerima. Hubungan komunikasi antara si pengirim dan si penerima, dibangun berdasarkan penyusunan kode atau simbol bahasa oleh pengirim dan pembongkaran ide atau simbol bahasa oleh penerima. Barelson dan Steiner (Ansari, 2016: 11), mengemukakan "Communication is the transmission of information, ideas, emotions, skills, etc, by the use of symbols-words, picturdes figures, graphs, etc (komunikasi adalah transmisi informasi, gagasan, emosi, keterampilan dan sebagainya dengan menggunakan simbol-simbol, kata-kata, gambar, grafik, dan sebagainya).

Secara umum komunikasi dipahami sebagai suatu bentuk aktivitas penyampaian informasi dalam suatu komunitas tertentu. Di dalam berkomunikasi tersebut harus dipikirkan bagaimana caranya agar pesan yang disampaikan seseorang itu dapat dipahami oleh orang lain. Untuk mengembangkan kemampuan berkomunikasi, orang dapat menyampaikan dengan berbagai bahasa termasuk bahasa matematis.

Josiah Willard Gibbs (Alisah dan Eko, 2007: 22) mengatakan bahwa "mathematics is a language" (matematika adalah sebuah bahasa). Ini artinya matematika merupakan sebuah cara mengungkapkan atau menerangkan secara tertentu. Matematika adalah bahasa yang melambangkan serangkaian makna dari pernyataan yang ingin kita sampaikan. Dalam hal ini, cara yang dipakai oleh bahasa matematika ialah dengan menggunakan simbol-simbol. Dimana simbol-simbol ini bersifat artifisial yang baru mempunyai arti setelah sebuah makna diberikan kepadanya.

Dengan demikian, komunikasi dalam matematika adalah suatu aktivitas penyampaian dan atau penerimaan gagasan-gagasan matematika dalam bahasa matematika. Penyampaian ide-ide atau gagasan menggunakan simbol-simbol, notasi-notasi dan lambang-lambang merupakan salah satu kemampuan komunikasi matematika.

Menurut Shadiq (Supriadi, 2011: 22) kemampuan komunikasi matematika adalah kemampuan seseorang dalam mengkomunikasikan ide-ide dan pikiran matematika. Komunikasi ide-ide, gagasan pada operasi atau pembuktian matematika banyak melibatkan kata-kata, lambang matematis dan bilangan. Sementara itu, Asikin (2002: 492) memberikan pengertian kemampuan komunikasi matematika mencakup dua hal, yakni kemampuan 
siswa menggunakan matematika sebagai alat komunikasi (bahasa matematika) dan kemampuan siswa mengomunikasikan matematika dipelajari sebagai isi pesan yang harus disampaikan.

Dari uraian di atas, dapat disimpulkan bahwa kemampuan komunikasi matematika adalah kemampuan seseorang dalam menyatakan dan menafsirkan gagasan matematika dan mendemonstrasikan apa yang ada dalam soal matematika.

Dengan berkembangnya kemampuan komunikasi matematika tersebut, siswa diharapkan dapat lebih menghargai dan memaknai matematika. Matematika tidak hanya dianggap sebagai bahasa simbol tanpa makna, melainkan dapat berguna untuk membantu memudahkan permasalahan yang dihadapi baik dalam dunia sekolah atau kehidupan sehari-hari siswa. Untuk mengetahui kemampuan komunikasi matematika siswa, perlu adanya indikator untuk mengukurnya. Siswa dikatakan telah memiliki kemampuan komunikasi matematika bilamana siswa telah menguasai indikator paradigma yang direkomendasikan NCTM (Ansari, 2016: 15) sebagai berikut: (1) menyatakan ide matematika dengan berbicara, menulis, demonstrasi, dan menggambarkannya dalam bentuk visual, (2) memahami, menginterpretasi, dan menilai ide matematik yang disajikan dalam tulisan, lisan atau bentuk visual, (3) menggunakan kosa kata/bahasa, notasi dan struktur matematik untuk menyatakan ide, menggambarkan hubungan, dan pembuatan model.

Berdasarkan kutipan di atas, dapat diketahui bahwa komunikasi matematika mencakup komunikasi tertulis maupun lisan atau verbal. Kemampuan komunikasi matematika lisan siswa dapat diukur saat siswa tersebut mengemukakan pengetahuan matematika mereka. Kemampuan komunikasi matematika tertulis dapat diukur melalui tulisan siswa mengenai matematika.

Komunikasi tertulis dapat berupa penggunaan kata-kata, gambar, tabel, dan sebagainya yang menggambarkan proses berpikir siswa. Komunikasi tertulis juga dapat berupa uraian pemecahan masalah atau pembuktian matematika yang menggambarkan kemampuan siswa dalam mengorganisasi berbagai konsep untuk menyelesaikan masalah. Sedangkan komunikasi lisan dapat berupa pengungkapan dan penjelasan verbal suatu gagasan matematika. Komunikasi lisan dapat terjadi melalui interaksi antarsiswa misalnya dalam pembelajaran dengan setting diskusi kelompok.

Untuk mengetahui kemampuan komunikasi matematis siswa pada penelitian ini, perlu adanya indikator untuk mengukurnya. Adapun indikator 
yang digunakan adalah indikator lisan menurut Djumhur dan indikator tulisan menurut Ross.

Indikator kemampuan komunikasi lisan menurut Djumhur (Fitriyani, 2015: 513), siswa dapat melakukan hal-hal berikut: (1) menyelesaikan suatu penyelesaian dari suatu masalah, (2) menggunakan tabel, gambar, model, dan lain-lain untuk menyampaikan jawaban dari suatu masalah, (3) memilih cara yang paling tepat untuk menyajikan jawaban dari suatu masalah, (4) memberikan saran atau pendapat lain untuk menjawab dari suatu pertanyaan yang lebih mudah, (5) merespon suatu pernyataan atau persoalan dari audiens dalam bentuk argumen yang meyakinkan, (6) mampu menginterpretasi dan mengevaluasi ide-ide, simbol, istilah, serta informasi matematis.

Indikator kemampuan komunikasi matematis siswa menurut Ross (Fitriyani, 2015: 513) dalam bentuk komunikasi tertulis yaitu: (1) menggambarkan situasi masalah dan menyatakan solusi masalah menggunakan gambar, tabel atau bagan secara aljabar, (b) menyatakan hasil dalam bentuk tertulis, (c) menggunakan representasi menyeluruh untuk menyatakan suatu konsep matematika dan solusinya, (d) membuat situasi matematika dengan menyediakan ide dan keterangan dalam bentuk tertulis, dan (e) menggunakan bahasa dan simbol matematika dengan tepat.

\section{PENDEKATAN REALISTIK}

Dalam pendidikan matematika, menurut Freudenthal (Abdussakir, 2010: 1) siswa bukanlah sekadar penerima yang pasif terhadap materi matematika yang siap saji, tetapi siswa perlu diberi kesempatan untuk reinvent (menemukan) matematika melalui praktik yang mereka alami sendiri. Suatu prinsip utama $R M E$ adalah siswa harus berpartisipasi secara aktif dalam proses belajar. Siswa harus diberi kesempatan untuk membangun pengetahuan dan pemahaman mereka sendiri.

RME menempatkan pemberian masalah nyata di awal pembelajaran. $R M E$ dimulai dengan pengajuan masalah yang kaya (rich problem), yakni masalah yang dapat diselesaikan dengan berbagai cara yang berbeda. De Lange (Fauzan, 2002: 35) menjelaskan bahwa proses pengembangan konsep dan ide matematika dimulai dari kehidupan nyata, dan menghubungkan solusi yang didapatkan, kembali kepada kehidupan nyata. Oleh karena itu, dapat dikatakan bahwa yang dilakukan dalam pembelajaran matematika adalah mengambil suatu permasalahan berdasarkan kenyataan, menjadikannya sebagai proses matematika, dan membawakannya lagi kepada kenyataan. Semua proses ini 
menuntun kepada pengertian matematika secara konseptual (conceptual matematization). Proses ini digambarkan oleh De Lange sebagai lingkaran yang tak berujung.

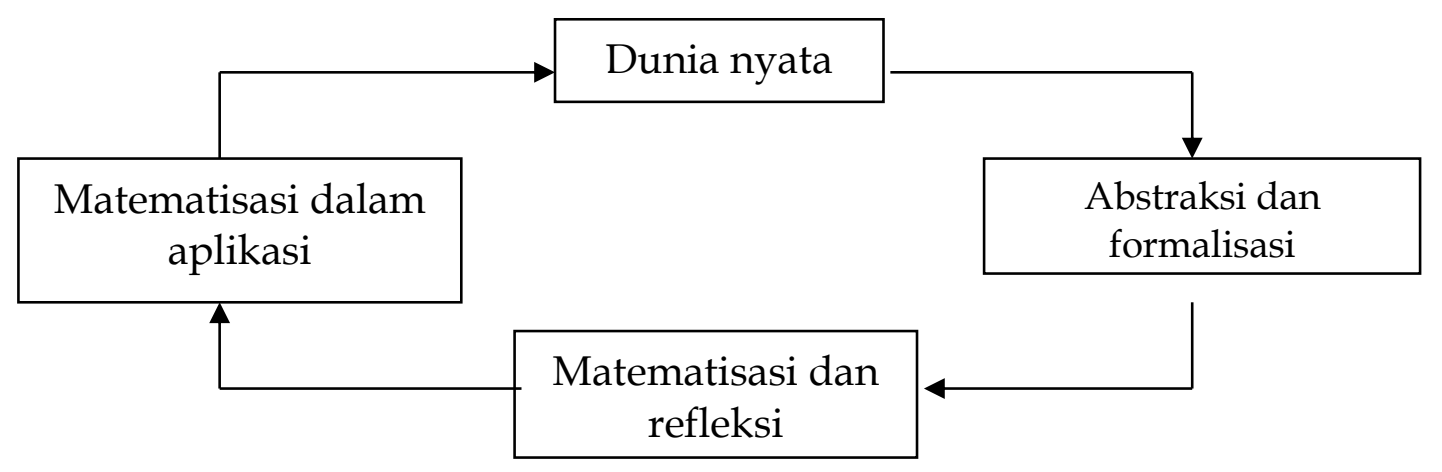

Gambar 1. Matematisasi Konseptual

Selanjutnya, oleh Treffers (Hadi, 2017:25) matematisasi dibedakan menjadi dua, yaitu matematisasi horizontal dan matematisasi vertikal. Kedua proses ini digambarkan oleh Graveimeijer sebagai proses penemuan kembali.

Dalam matematisasi horisontal, siswa mulai dari soal-soal kontekstual, mencoba menguraikan dengan bahasa dan simbol yang dibuat sendiri, kemudian menyelesaikan soal tersebut. Dalam proses ini, setiap orang dapat menggunakan cara mereka sendiri yang mungkin berbeda dengan orang lain. Sedangkan matematisasi vertikal adalah proses mengorganisasi ulang oleh siswa di dalam sistem matematika. Dalam matematisasi vertikal, siswa juga mulai dari soal-soal kontekstual, tetapi dalam jangka panjang kita dapat menyusun prosedur tertentu yang dapat digunakan untuk menyelesaikan soalsoal sejenis secara langsung, tanpa bantuan konteks. 


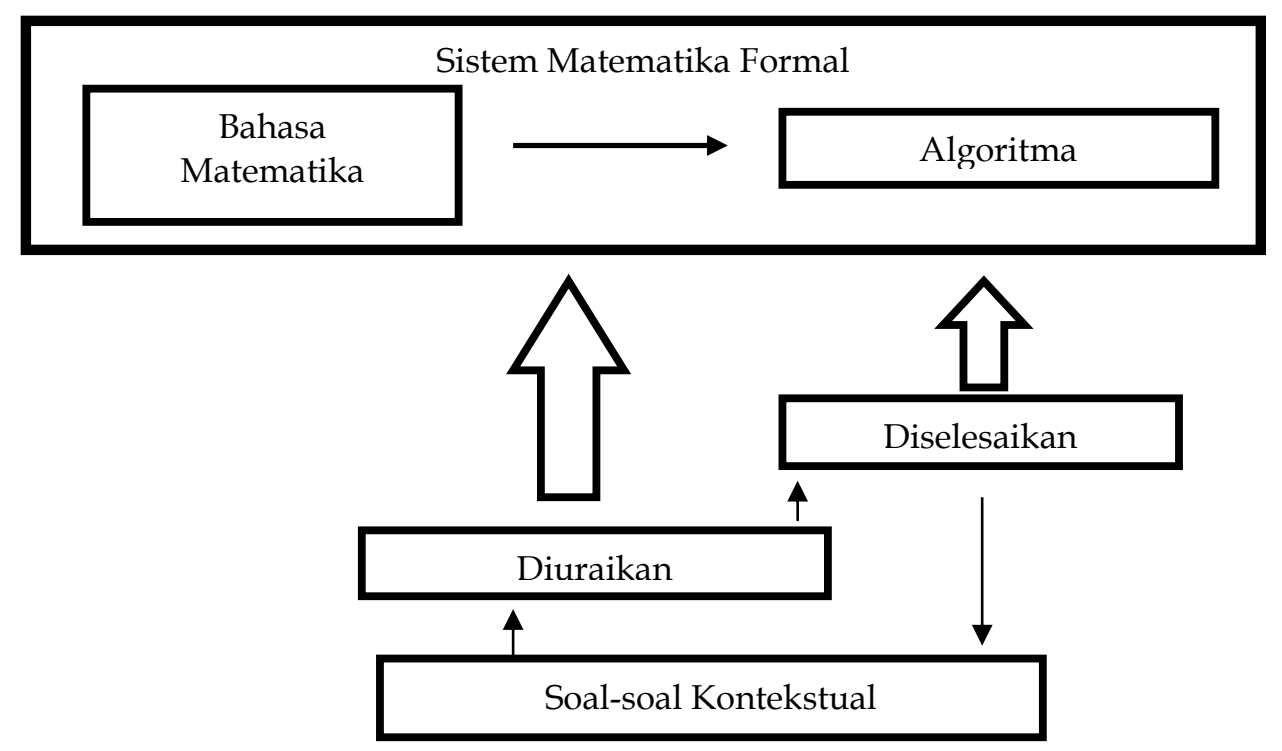

Gambar 2. Matematisasi Horisontal dan Vertikal

\section{PENDEKATAN REALISTIK SETTING KOOPERATIF}

Pembelajaran kooperatif (cooperative learning) merupakan bentuk pembelajaran dengan cara siswa belajar dan bekerja dalam kelompokkelompok kecil secara kolaboratif dengan struktur kelompok yang bersifat heterogen (Rusman, 2011: 203). Dalam pembelajaran kooperatif proses pembelajaran tidak harus belajar dari guru kepada siwa. Siswa dapat saling membelajarkan sesama siswa lainnya. Tiga konsep sentral yang menjadi karakteristik pembelajaran kooperatif yaitu penghargaan kelompok, pertanggungjawaban individu, dan kesempatan bersama untuk berhasil.

Menurut Wang (2009), terdapat enam langkah utama di dalam pembelajaran kooperatif di kelas. Langkah-langkah ini disajikan dalam tabel 1 berikut. 
Tabel 1. Langkah-langkah Pembelajaran Kooperatif

\begin{tabular}{|c|c|}
\hline Fase & Langkah Guru \\
\hline $\begin{array}{r}\text { Fase 1: Menyampaikan } \\
\text { tujuan dan } \\
\text { memotivasi siswa }\end{array}$ & $\begin{array}{l}\text { Guru menyampaikan semua tujuan } \\
\text { pembelajaran dan mengomunikasikan } \\
\text { kompetensi dasar yang akan dicapai serta } \\
\text { memotivasi siswa belajar. }\end{array}$ \\
\hline $\begin{array}{ll}\text { Fase } & \text { 2: Menyajikan } \\
& \text { informasi }\end{array}$ & $\begin{array}{l}\text { Guru menyajikan informasi kepada siswa } \\
\text { dengan jalan demonstrasi atau lewat bahan } \\
\text { bacaan. }\end{array}$ \\
\hline $\begin{array}{l}\text { Fase 3: } \text { Mengorgani- } \\
\begin{array}{ll}\text { sasikan siswa ke } \\
\text { dalam kelompok } \\
\text { kooperatif }\end{array}\end{array}$ & $\begin{array}{l}\text { Guru menjelaskan kepada siswa bagaimana } \\
\text { caranya membentuk kelompok belajar dan } \\
\text { membantu setiap kelompok agar melakukan } \\
\text { transisi secara efisien. }\end{array}$ \\
\hline $\begin{array}{ll}\text { Fase } & 4: \text { Membimbing } \\
& \text { kelompok bekerja } \\
& \text { dan belajar }\end{array}$ & $\begin{array}{l}\text { Guru membimbing kelompok-kelompok } \\
\text { belajar pada saat mereka mengerjakan tugas } \\
\text { mereka. }\end{array}$ \\
\hline Fase 5: Evaluasi & $\begin{array}{l}\text { Guru mengevaluasi hasil belajar tentang } \\
\text { materi yang telah dipelajari atau masing- } \\
\text { masing kelompok mempresentasikan hasil } \\
\text { kerjanya. }\end{array}$ \\
\hline $\begin{array}{ll}\text { Fase } & 6: \quad \text { Memberikan } \\
& \text { penghargaan }\end{array}$ & $\begin{array}{l}\text { Guru mencari cara-cara untuk menghargai } \\
\text { baik upaya maupun hasil belajar individu } \\
\text { maupun kelompok }\end{array}$ \\
\hline
\end{tabular}


Secara skematis, kerangka pikir penelitian ini digambarkan sebagai berikut:

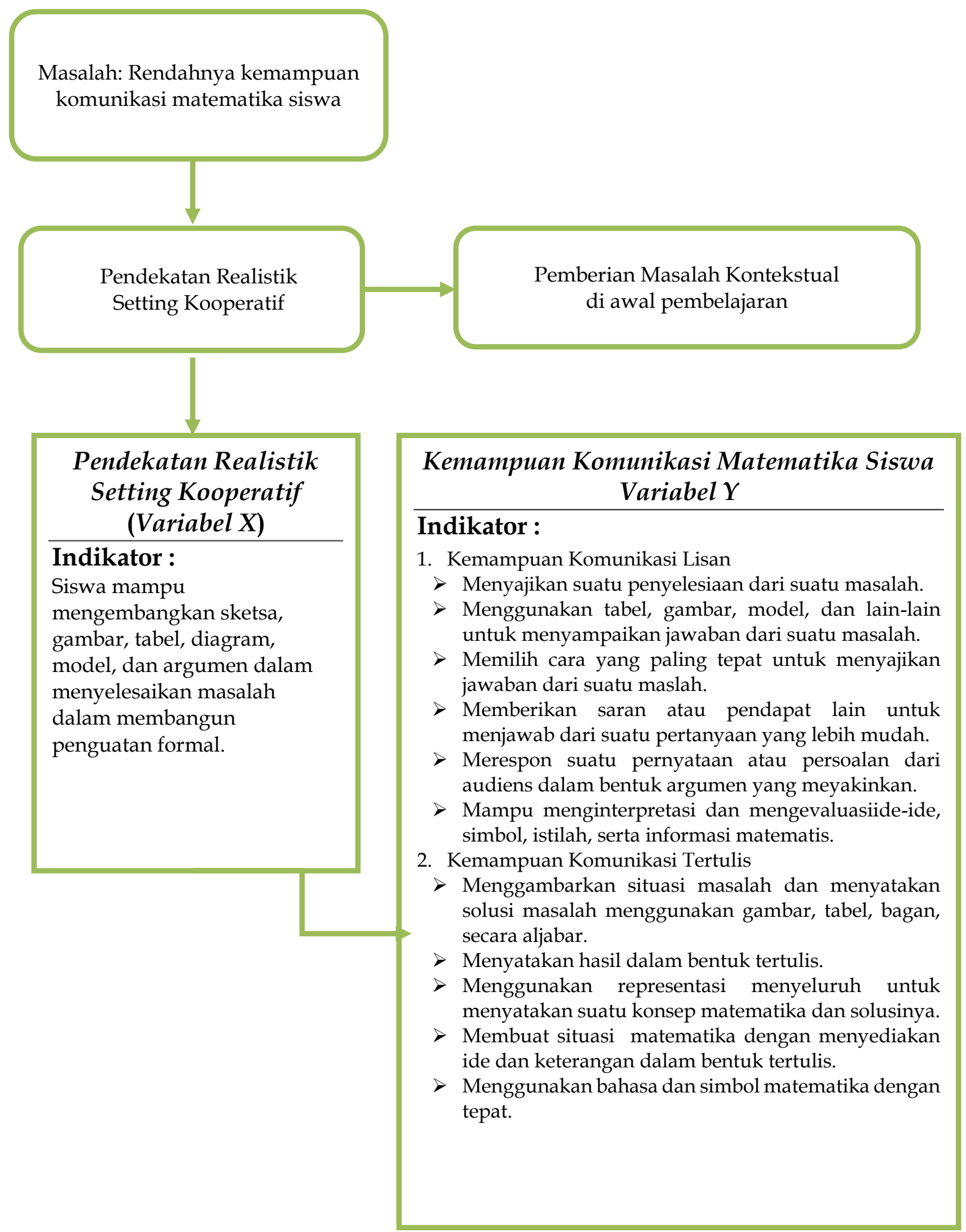

Gambar 3. Kerangka Pikir 
Berdasarkan kajian pustaka dan kerangka pikir sebelumnya maka kemampuan komunikasi matematika siswa dilakukan dengan hipotesis statistik berikut ini:

$\mathrm{H}_{0}: \mu_{\mathrm{B}} \leq 0$ melawan $\mathrm{H}_{0}: \mu_{\mathrm{B}}>0$

Dimana: $\mu_{B}=\mu_{2}-\mu_{1}$

Keterangan:

$\mathrm{H}_{1} \quad$ : Ada pengaruh pendekatan realistik setting kooperatif terhadap kemampuan komunikasi matematika siswa.

$\mathrm{H}_{0} \quad$ : Tidak ada pengaruh pendekatan realistik setting kooperatif terhadap kemampuan komunikasi matematika siswa.

$\mu_{1} \quad$ : Parameter skor rata-rata hasil tes sebelum pembelajaran (Pretest)

$\mathrm{\mu}_{2} \quad$ : Parameter skor rata-rata hasil tes setelah pembelajaran (Posttest)

\section{METODE PENELITIAN}

Metode penelitian yang digunakan dalam penelitian ini adalah eksperimen. Satuan eksperimen dalam penelitian ini yaitu siswa kelas VIII di SMP Muhammadiyah 6 Makassar tahun ajaran 2017/2018 pada semester ganjil yang kemudian dengan menggunakan teknik purposive sampling terpilih kelas VIII B. Tujuan dan pertimbangan pengambilan subjek/sampel penelitian ini adalah sampel tersebut memiliki kemampuan komunikasi yang rendah dibanding kelas $\mathrm{VIII}_{\mathrm{A}}$. Hal ini terlihat melalui hasil ulangan sekolah siswa yang masih sangat rendah.

Instrumen penelitian merupakan alat pengumpulan data penelitian yang dapat menunjang sejumlah data yang diasumsikan (Yusuf, 2013), dapat digunakan untuk menjawab pertanyaan-pertanyaan dan menguji hipotesis penelitian (Sugiyono, 2010).

Instrumen yang akan digunakan dalam penelitian ini adalah sebagai berikut:

a. Tes

Tes kemampuan komunikasi matematika bertujuan untuk memperoleh data kuantitatif berupa skor kemampuan komunikasi tertulis siswa yang disusun berdasarkan indikator kemampuan komunikasi matematika. Tes yang diberikan meliputi pre-test dan post-test dalam bentuk essai. Pre-test diberikan siswa sebelum mendapat perlakuan, sedangkan post-test diberikan kepada siswa setelah mendapatkan perlakuan. Untuk pemberian skor pada setiap 
butir soal tes komunikasi matematika ini dilakukan berdasarkan Holistic Scoring Rubrics.

Tabel 2. Pedoman Pemberian Skor Kemampuan Komunikasi Matematika

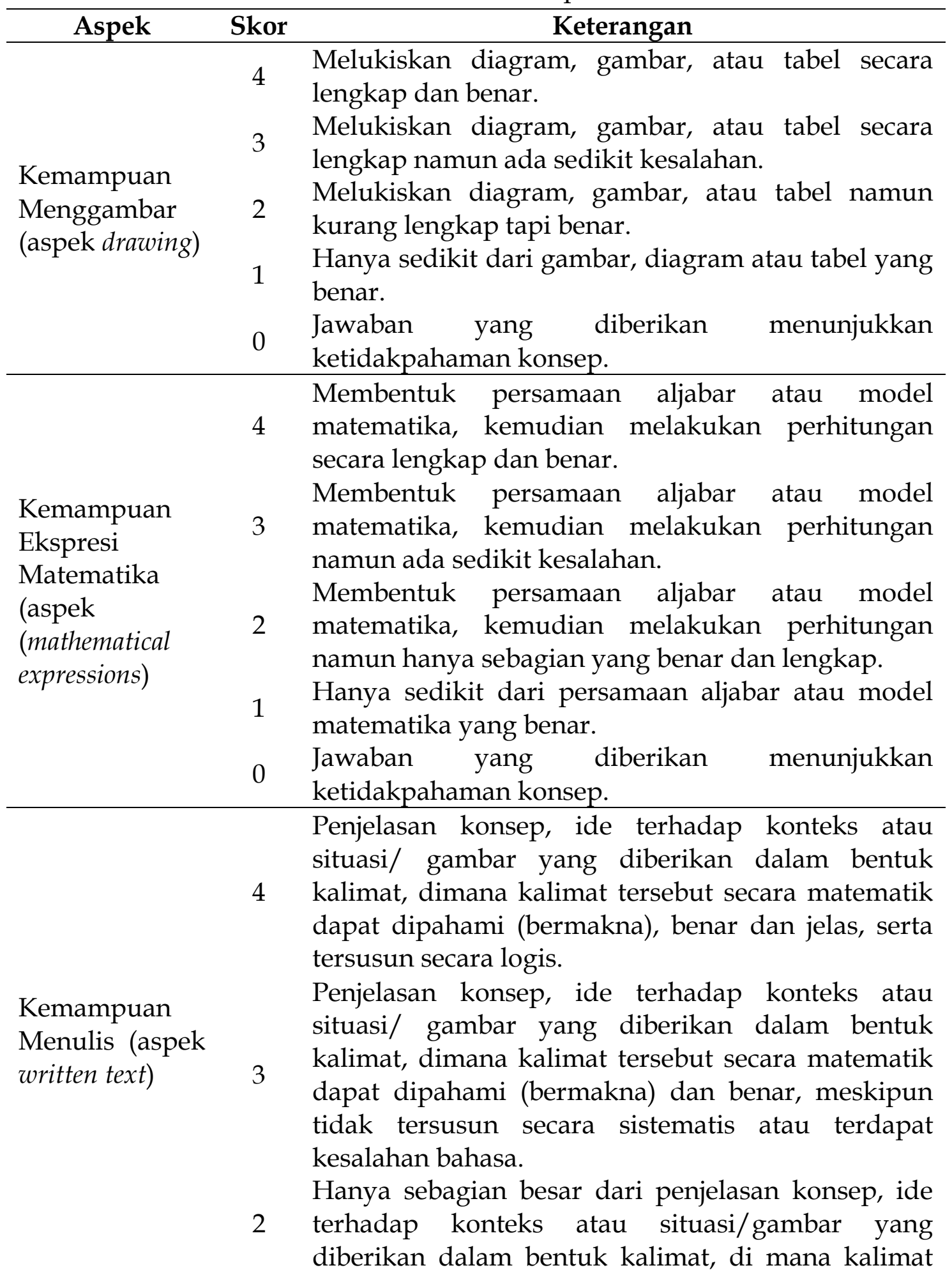


tersebut secara matematik dapat dipahami (bermakna) danbenar

Hanya sedikit dari penjelasan konsep, ide terhadap

1 konteks atau situasi/gambar yang diberikan dalam bentuk kalimat, dimana kalimat tersebut secara matematik dapat dipahami (bermakna) dan benar.

0 Jawaban yang diberikan menunjukkan ketidakpahaman konsep.

\section{b. Lembar Observasi}

Lembar observasi yang digunakan terbagi atas 2 yakni lembar observasi untuk mengamati kemampuan komunikasi matematika siswa kelas $\mathrm{VIII}_{\mathrm{B}}$ SMP Muhammadiyah 6 Makassar dari segi lisan dengan mengacu terhadap indikator yang telah ditentukan, yang dilaksanakan saat berlangsungnya proses pembelajaran selama pelaksanaan penelitian melalui penerapan pendekatan realistik setting kooperatif dan lembar observasi kemampuan guru dalam mengelola pembelajaran dengan penerapan pendekatan realistik setting kooperatif.

Tabel. 3 Kategori Keterlaksanaan Pembelajaran

\begin{tabular}{cc}
\hline Interval Skor & Kategori \\
\hline $3,00<\overline{\mathrm{X}} \leq 4,00$ & Sangat Baik \\
$2,00<\overline{\mathrm{X}} \leq 3,00$ & Baik \\
$1,00<\overline{\mathrm{X}} \leq 2,00$ & Kurang Baik \\
$\overline{\mathrm{X}} \leq 1,00$ & Tidak Baik \\
\hline
\end{tabular}

\section{c. Angket}

Angket adalah sejumlah pertanyaan tertulis untuk memperoleh tanggapan siswa terhadap pembelajaran yang dilakukan selama penelitian berlangsung. Angket diberikan kepada siswa pada akhir kegiatan pembelajaran. Data respons siswa dianalisis dengan melihat skor rata-rata respons siswa. Artinya tingkat respons siswa dihitung dengan cara menjumlah rata-rata skor tiap responden dibagi dengan banyaknya responden. Namun sebelum menghitung rata-rata respons siswa, perlu dihitung pula jumlah rata-rata untuk tiap responden dengan cara jumlah skor penilaian setiap aspek yang direspon dibagi dengan banyaknya aspek yang direspons. 


\section{HASIL PENELITIAN DAN PEMBAHASAN}

Pada pembahasan hasil analisis deskriptif meliputi kemampuan komunikasi matematika siswa, kemampuan komunikasi lisan siswa dalam proses pembelajaran melalui pembelajaran pendekatan realistik setting kooperatif, keterlaksanaan pembelajaran, serta respons siswa terhadap proses pembelajaran pendekatan realistik setting kooperatif akan diuraikan sebagai berikut:

a. Kemampuan Komunikasi Matematika Siswa

Kemampuan komunikasi matematika siswa sebelum dan setelah diajar dengan pendekatan realistik setting kooperatif diuraikan sebagai berikut:

Tabel 4. Statistik Skor Pre-Test Kemampuan Komunikasi Matematika Siswa

\begin{tabular}{cc}
\hline Statistik & Nilai Statistik \\
\hline Ukuran Sampel & 33 \\
Skor Ideal & 60 \\
Nilai Terendah & 0 \\
Nilai Tertinggi & 12 \\
Rentang & 12 \\
Mean (Rata-Rata) & 6,15 \\
Median & 6 \\
Standar Deviasi & 4,00 \\
Variansi & 16,07 \\
\hline
\end{tabular}

Kemampuan komunikasi matematika siswa sebelum diajar dengan pendekatan realistik setting kooperatif memiliki rata-rata sebesar 6,15, median 6, skor terendah 0 , skor tertinggi 12, standar deviasi 4,00 dari skor ideal 60 dengan rata-rata skor pada indikator menggambar, ekspresi matematika dan menulis secara berturut-turut adalah 0,61, 4,24, dan 1,3.

Tabel 5. Statistik Skor Post-Test Kemampuan Komunikasi Matematika Siswa

\begin{tabular}{cc}
\hline Statistik & Nilai Statistik \\
\hline Ukuran Sampel & 33 \\
Skor Ideal & 60 \\
Nilai Terendah & 15 \\
Nilai Tertinggi & 52 \\
Rentang & 37 \\
Mean (Rata-Rata) & 29,93 \\
Median & 27 \\
Standar Deviasi & 11,08 \\
Variansi & 122,87 \\
\hline
\end{tabular}


Kemampuan komunikasi matematika siswa setelah diajar dengan pendekatan realistik setting kooperatif memiliki rata-rata sebesar 29,93, median 27, skor terendah 15, skor tertinggi 52, standar deviasi 11,08 dari skor ideal 60 dengan rata-rata skor pada indikator menggambar, ekspresi matematika dan menulis secara berturut-turut adalah 8,18, 12,88, dan 8,39.

Tabel 6. Deskripsi Data Peningkatan (Gain) Kemampuan Komunikasi Matematika Siswa

\begin{tabular}{cc} 
Matematika Siswa & Nilai Statistik \\
\hline Statistik & 33 \\
Ukuran Sampel & 60 \\
Skor Ideal & 0,12 \\
Nilai Terendah & 0,85 \\
Nilai Tertinggi & 0,73 \\
Rentang & 0,44 \\
Mean (Rata-Rata) & 0,4 \\
Median & 0,19 \\
Standar Deviasi & 0,038 \\
Variansi &
\end{tabular}

Peningkatan kemampuan komunikasi matematika siswa yang diajar dengan pendekatan realistik setting kooperatif memiliki rata-rata skor gain ternormalisasi sebesar 0,44 dengan standar deviasi 0.19. Terdapat 5 siswa mengalami peningkatan tinggi, 21 siswa mengalami peningkatan sedang, dan 7 siswa mengalami peningkatan dengan kategori rendah. Jika dilihat dari indikator komunikasi matematika, rata-rata skor gain ternormalisasi pada indikator menggambar, ekspresi matematika dan menulis secara berturut-turut adalah sebesar 0,39, 0.55, dan 0,38.

Berdasarkan analisis deskriptif pada setiap indikator komunikasi matematika, kemampuan komunikasi matematika siswa yang setelah diajar dengan pendekatan realistik setting kooperatif lebih tinggi daripada kemampuan komunikasi matematika siswa sebelum diajar dengan pendekatan realistik setting kooperatif.

b. Kemampuan Komunikasi Lisan Siswa

Hasil pengamatan kemampuan komunikasi lisan siswa dalam pembelajaran matematika melalui penerapan pendekatan realistik setting kooperatif pada siswa kelas VIII $\mathrm{B}$ SMP Muhammadiyah 6 Makassar menunjukkan bahwa perolehan rata-rata persentasi kemampuan komunikasi 
matematika siswa yaitu sebanyak 76,63\% memenuhi indikator yang telah ditetapkan. Kriteria keberhasilan kemampuan komunikasi lisan siswa dalam penelitian ini diakatakan efektif apabila minimal 75\% siswa memenuhi indikator yang telah ditetapkan. Dengan demikian, penerapan pendekatan realistik setting kooperatif dapat meningkatkan kemampuan komunikasi lisan siswa.

c. Respons Siswa

Berdasarkan hasil analisis respons siswa diperoleh bahwa 88\% siswa memberikan respons positif terhadap pelaksanaan pembelajaran matematika melalui penerapan pendekatan realistik setting kooperatif. Dari hasil analisis tersebut menunjukkan bahwa pembelajaran melalui penerapan pendekatan realistik setting kooperatif telah mencapai indikator efektivitas yang dijadikan tolak ukur, dimana respons positif minimal 75\% dari keseluruhan responden.

Dengan demikian, dari hasil analisis data yang diperoleh menunjukkan bahwa kemampuan komunikasi matematika siswa meningkat, kemampuan komunikasi lisan siswa mencapai kriteria berhasil, keterlaksanaan model pembelajaran berada pada kategori terlaksana dengan sangat baik, serta respons siwa terhadap proses pembelajaran melalui pembelajaran pendekatan realistik setting kooperatif cenderung positif, maka dapat disimpulkan bahwa "terdapat pengaruh penerapan pendekatan realistik setting kooperatif terhadap kemampuan komunikasi matematika siswa kelas VIII SMP Muhammadiyah 6 Makassar" .

\section{SIMPULAN}

Berdasarkan hasil analisis dan pembahasan maka dapat ditarik beberapa kesimpulan bahwa:

a. Keterlaksanaan pembelajaran melalui penerapan pendekatan realistik setting kooperatif berada pada kategori terlaksana dengan sangat baik dengan rata-rata 3,6 .

b. Dari hasil analisis deskriptif menunjukkan bahwa kemampuan komunikasi matematika siswa setelah diajar dengan pendekatan realistik setting kooperatif memiliki rata-rata sebesar 29,93, median 27, skor terendah 15, skor tertinggi 52, standar deviasi 11,08 dari skor ideal 60 dengan rata-rata skor pada indikator menggambar, ekspresi matematika dan menulis secara berturut-turut adalah 8,18, 12,88, dan 8,39.

c. Peningkatan kemampuan komunikasi matematika siswa yang diajar dengan pendekatan realistik setting kooperatif memiliki rata-rata skor gain 
ternormalisasi sebesar 0,44 dengan standar deviasi 0,19, 5 siswa mengalami peningkatan tinggi, 21 siswa mengalami peningkatan sedang, dan 7 siswa mengalami peningkatan rendah. Jika dilihat dari indikator komunikasi matematika, rata-rata skor gain ternormalisasi pada indikator menggambar, ekspresi matematika dan menulis secara berturut-turut adalah sebesar 0,39, 0.55 , dan 0,38 .

d. Kemampuan komunikasi lisan siswa yang berkaitan dengan kegiatan pembelajaran berdasarkan indikator kemampuan komunikasi lisan secara keseluruhan dikatakan cukup berhasil. Hal ini ditunjukkan dengan perolehan rata-rata persentasi kemampuan komunikasi lisan siswa 76,63\%.

e. Pembelajaran melalui penerapan pendekatan realistik setting kooperatif pada siswa kelas VIII $\mathrm{I}_{\mathrm{B}} \mathrm{SMP}$ Muhammadiyah 6 Makassar mendapat respons positif dengan rata-rata persentase siswa yang memberi respons positif sebesar $88 \%$ dari jumlah keseluruhan siswa.

f. Berdasarkan hasil analisis yang diperoleh dengan menggunakan SPSS menunjukkan bahwa $t_{\text {hitung }}=15,516$ dan $t_{\text {tabel }}$ sebesar 2,036 ini membuktikan bahwa thitung $\geq t_{\text {tabel }}$ dengan nilai $15,516 \geq 2,036$ selain itu dengan nilai signifikansi $0,000<$ dari taraf signifikan 0,05 sehingga $\mathrm{H}_{1}$ diterima dan $\mathrm{H}_{0}$ ditolak, hal ini membuktikan bahwa terdapat pengaruh pendekatan realistik setting kooperatifterhadap kemampuan komunikasi matematika siswa.

\section{DAFTAR PUSTAKA}

Abdussakir. (2010). Realistic Mathematics Education (RME) dan penerapannya di MI (Online). $\quad$ http:// repository.uin-malang.ac.id/1730/7/1730.pdf. (Diakses pada tanggal 29 Oktober 2016, pukul 15:00).

Alisah, E. \& Eko P.D. (2007). Filsafat dunia matematika: pengantar untuk memahami Konsep-konsep matematika. Jakarta: Prestasi Pustaka Publisher.

Ansari, I.B. (2016). Komunikasi matematik (konsep dan aplikasi). Banda Aceh: Yayasan Pena.

Arends, R.I. (2008). Learning to teach (belajar untuk mengajar). Yogyakarta: Pustaka Belajar.

Asikin, M. (2002). Menumbuhkan kemampuan komunikasi matematika melalui pembelajaran matematika realistik. Jurnal Matematika Edisi Khusus. 
Fauzan, A. (2002). Applying realistic mathematics education in teaching geometry in indonesian primary schools. Thesis University of Twente. Enschede: Print Partners Ipskamp Press. (Online). http://doc.utwente.nl/58707/1/thesis_Fauzan.pdf. (Download pada tanggal 25 Oktober 2016 pukul 20:00).

Fitriyani, H. (2015). peningkatan kemampuan komunikasi matematis mahasiswa calon guru melalui pembelajaran investigasi (online). https:// publikasiilmiah.ums.ac.id/bitstream/handle/11617/7856/62.p df?sequence=1. (Diakses pada tanggal 25 Oktober 2016 pukul 22:18).

Hadi, S. (2017). Pendidikan matematika realistik (teori, pengembangan dan implementasinya). Jakarta: Rajawali Pers.

Mahmudi, A. (2009). Komunikasi dalam pembelajaran matematika. Jurnal MIPMIPA UNHALU, 8(1).

Rusman. (2011). Model-model pembelajaran mengembangkan profesionalisme guru. Jakarta: PT. Rajagrafindo Persada.

Sagala, S. (2010). Konsep dan makna pembelajaran. Bandung: Alfabeta.

Sugiyono. (2010). Metode penelitian kuantitatif kualitatif dan RED. Bandung: Alfabeta.

Sukardi. (2011). Metodologi penelitian pendidikan. Jakarta: Bumi Aksara.

Supriadi. (2011). Pengaruh pembelajaran dengan pendekatan open-ended problem dan problem solving terhadap kemampuan penalaran dan komunikasi matematika siswa SMA Negeri 1 Sinjai Borong Kabupaten Sinjai. Tesis. Makassar: FMIPA Pascasarjana UNM.

Trianto. (2011). Mendesain model pembelajaran inovatif-progresif: konsep, landasan, dan implementasinya pada Kurikulum Tingkat Satuan Pendidikan (KTSP). Jakarta: Kencana.

Wang, T. (2009). Applying Slavin's cooperative learning techniques to a collage EFL conversation class (online). http://www.hrajournal.com/Page/13\%20Tzu-pu\%Wang.pdf. (Diakses pada tanggal 2 November 2016 pukul 17:58). 
Pengembangan Penerapan Pendekatan Realistik....

Yusuf, M. (2013). Metode penelitian (kuantitatif, kualitatif dan penelitian gabungan). Jakarta: Kencana Prenada. 